\title{
Mutations in components of antiviral or microbial defense as a basis for breast cancer
}

\author{
Bernard Friedenson \\ Dept. of Biochemistry and Molecular Genetics \\ College of Medicine \\ University of Illinois Chicago \\ Correspondence to: Bernard Friedenson \\ email: molmeddoc@yahoo.com \\ Telephone/Fax 847-298-I64I
}


In-depth functional analyses of thousands of breast cancer gene mutations reveals vastly different sets of mutated genes in each of 21 different breast cancer genomes. Despite differences in which genes are mutated, innate immunity pathways and metabolic reactions supporting them are always damaged. These functions depend on many different genes. Mutations may be rare individually but each set of mutations affects some aspect of pathogen recognition and defense, especially those involving viruses. Some mutations cause a dysregulated immune response, which can also increase cancer risks. The frequency of an individual mutation may be less important than its effect on function. This work demonstrates that acquired immune deficiencies and dysregulation in cancer can occur because of mutations. Abnormal immune responses represent a hidden variable in breast cancer - viral association studies. Compensating for these abnormalities may open many new opportunities for cancer prevention and therapy.

\section{Keywords}

Breast cancer infection, breast cancer immunity, breast cancer virus, genome biochemistry 


\section{Introduction}

An in-depth analysis of thousands of breast cancer gene mutations in 21 different breast cancer genomes may provide a clearer view of how cancer originates. The analysis revealed vastly different sets of mutated genes in every breast cancer with only occasional genes mutated in more than one breast cancer. Immune and antiviral functions protecting against pathogens are complex, requiring many genes dispersed throughout the genome. Mutations in many different genes can disable some aspect of immunity or other defenses, causing acquired immunodeficiency states and increase susceptibility to cancer. Some mutations cause a dysregulated immune response, which also increases cancer risks. Mutations in a specific gene may occur more than once but the frequency of an individual mutation may be less important than its effect on function. This view might permit more effective approaches to prevention and therapy because it suggests compensating for or exploiting functional deficits as distinct from trying to exploit individual specific abnormalities in a few shared driver genes.

As causes of breast cancer, some studies implicate tumor viruses such as a human form of mouse mammary tumor virus (HMTV), Epstein Barr virus (EBV) or human papilloma virus (HPV) (Glenn et al. 20I2). HMTV, for example, occurs in human mammary epithelium; antibodies have been reported; HMTV-breast cancer associations correlate with geographical prevalence of mice; viral particles have been isolated from primary cultures of human breast cancer cells; $5 \%$ of breast milk samples contain viral sequences; and MMTV can infect human mammary epithelial cells (Holland and Pogo 20I2). Mouse mammary tumor virus causes breast cancer in mice.

But no single virus is always found in breast cancer and the idea that a virus causes breast cancer remains controversial. Despite well-done experiments, exactly opposite results from different groups suggest "lurking variables" are not being considered. One such additional variable is the condition of the immune response.

The immune response to pathogens utilizes both immediate (innate) and delayed (adaptive or induced) immune responses. Because many pathogens can multiply quickly, a rapid innate response is essential to allow time until a more specific and effective adaptive immune response can develop. The mammary gland probably evolved from the innate immune system (Vorbach et al. 2006). Conserved signaling pathways are involved in immunity as well as in the development and function of the mammary gland. Lactation, as constituted today, evolved as an inflammatory response to tissue damage and infection and inflammatory molecules became key regulators (Vorbach et al. 2006). 
A host derived immune response probably always accompanies human breast cancer. Breast cancers are heavily infiltrated with cells from the immune system within the tumor or the stroma. Among 3403 cases, CD8+ tumor infiltrating lymphocytes were in the tumor in $32 \%$ and in the stroma in $61 \%$ of the cases (Liu et al. 2012). Lymphoid infiltrates are found in about half the prophylactic mastectomies from BRCA2 mutation carriers, who have a high risk of breast cancer. Results of studying such surgically removed breast tissues clearly show immune responses occur even before cancer can be detected (Hermsen et al. 2005).

There are different kinds of immune cells within infiltrates in breast cancers and their stroma. These immune responses are unable to prevent or clear breast cancer. This failure may be because mutations impair the immune response or cause its dysregulation so that it can even potentiate cancer. There is a general immune system dysfunction in breast cancer patients with impaired production of interferon gamma and other cytokines (Campbell et al. 2005). Alterations in chemokine levels are associated with cancer progression (Porter et al. 2003). NK cell activity from the innate immune system was significantly lower in individuals with strong family histories of breast cancer vs. individuals without this history (Cunningham-Rundles et al. 198I). Even early stage breast cancer patients lose immune functions (Poschke et al. 20I2). In breast cancer patients, regulatory $\mathrm{T}$-cells in malignant lesions curtail other $\mathrm{T}$-cell and $\mathrm{NK}$ cell responses (Curigliano 20 II). Common genetic variants in innate immunity genes are strongly associated with breast cancer risk in Korean women (Lee et al. 2009). Defects in pathways mediated by BRCAI and BRCA2 "breast cancer genes" are associated with cancers involving the immune system (Friedenson 2007) and impaired immunity. Variants of breast cancer cell lines are aggressively metastatic in immunodeficient mice.

Suppression of an innate immune pathway intrinsic to breast cancer cells restricts immune surveillance to enable metastasis (Bidwell et al. 20I2)

Innate immune sensors that can recognize foreign nucleic acids from viral infections exist in breast and in most other cells. These sensors such as the Toll-like receptors (TLRs) then induce cellular and molecular effectors with broad antiviral activity and promote inflammation to increase potency of adaptive immune responses. All ten known TLRs have been found in breast cancers and in breast milk. Specifically, 60 tumor samples ( $80 \%$ of those tested) were positive for TLR5. TLR5 was highly expressed in most invasive ductal carcinomas (IDC) and moderately expressed in medullary carcinomas and invasive lobular carcinoma (Cai et al. 20l Ib). Retinoic acid can induce the intrinsic ability of breast cancer cells to recognize double-stranded RNA through the up regulation 
of TLR3 expression (Bernardo et al. 2013). TLR4 expression in 50 primary invasive ductal carcinoma and 17 lymph node sections was significantly associated with local metastasis and tumor grade (Ehsan et al. 20I3). Low tumor TLR9 expression is associated with significantly shortened disease-specific survival in patients with triple negative but not with ER+ breast cancers (Tuomela et al. 20I2). Members of the TLR9 subfamily are RNA (TLRs 3, 7, and 8) and DNA (TLR9) receptors.

Additional innate immune sensors include the RIG-I helicase family, cytosolic helicases that primarily sense viral RNA. NLRP3, one of the cytoplasmic nucleotide oligomerization domain (NOD) -like receptors, can also recognize viral RNA and DNA. Scavenger receptors can modulate infectivity of Hepatitis $C$ virus. Other proteins with antiviral activity have not been placed in the innate or adaptive immune system.

The recent availability of breast cancer genomic sequences permits considering the possibility that breast cancers develop because of varying losses in protective immune function or because of its dysregulation. These abnormalities could represent a significant variable in virus-breast cancer association studies but an abnormal immune response could contribute to breast cancer whatever its cause. Publicly available data from 21 different breast cancer genomes was researched in depth looking for mutations, deletions, and rearrangement of genes essential for breast immune responses.

Abnormalities in genes required for innate immunity and its regulation in breast cancer cells. Figs. I-2 are examples that outline steps in pathways where mutations have damaged defenses against RNA and DNA tumor viruses, respectively. Table I documents examples of breast cancer mutations affecting immune response functions and/or their regulation. Tables I-2 also includes mutations not shown in Figs I2 expected to affect immune responses. Multiple components of immune defenses are mutated in every one of 21 breast cancer genomes. Mutations also dysregulate the immune response (Table I) and may also contribute to cancer i.e. by causing chronic inflammation. The mutations are indicated in the Figures as affecting processes such as cytokine production, autophagy, etc. rather than as affecting specific genes. Breast cancer mutations always involved these common functions or their regulation. The affected functions depend on many genes dispersed throughout the genome so most genes are only mutated in one cancer. Mutations in the same gene are uncommon and each breast cancer genome has a different set of these mutations.

Antigen recognition, signaling essential to transmit the immune responses, and immune regulation can all be damaged. Large differences exist in distributions and numbers of mutations among the breast cancer genomes. There are also large differences 
in the numbers of DNA breaks, and non-coding mutations (Nik-Zainal et al. 2012). Despite these differences, major common properties of many mutations is that they cripple some aspect of innate immunity, its regulation, or its connections to adaptive immunity. Damage to some gene products shown in Figs. I-2 can potentially dysregulate immunity and inflammation in breast cancers (Table I), damaging specific responses to antigens or to pathogens. Dysregulation could conceivably result from mutations alone without exposure to antigens or pathogens, impairing host response to breast cancer whatever its cause. For example, in breast cancer PD3905a, mutation occurs in ILIR2 within the interleukin receptor gene cluster. Inactivity of IL-IR2 generates an inflammatory necrotic phenotype (Zheng et al. 20I3). In breast cancers PD3905a, PD4 I03a, and PD4 I I 6 a regulators of autophagy and lysosomal trafficking are damaged. In PD4 I07a, mutation occurs in the IFNGRI gene, which has crucial roles in regulating both innate and adaptive immunity. In breast cancers PD4 I03a and PD4 I20a, GATA3, a critical early regulator of innate lymphoid cell development is mutated. Many breast cancer mutations cause defects in antiviral defenses, increasing risks for viral infections in the breast.

\section{Examples of damage to specific genes encoding antiviral defenses in} different breast cancers. During infection by RNA viruses, single- and double-stranded RNA are recognized by the host and induce innate immune responses by several proposed mechanisms (Fig. I). Viral products such as 5'- PPP-RNA represent a foreign molecular signature that distinguishes it from normal host nucleic acids. Host proteins responsible for sensing or interacting with such foreign nucleic acids include the TLR's present in the breast. IFITs (interferon-induced protein with tetratricopeptide repeats) are among the most potently expressed proteins of a group of interferon-stimulated genes, which result from virally triggered signaling pathways that lead to the production of interferons and other cytokines (Abbas et al. 20I3). IFITs directly engage PPP-RNA and a group of them is deleted in breast cancer PD3904a (Table I).

The cellular enzyme ADAR (adenosine deaminase acting on RNA) is stimulated by interferon in virally infected cells. Normally ADAR leads to the presence of inosinecontaining RNA. Inosine RNA may then further stimulate breast innate immunity. The ADAR gene is involved in an inter-chromosomal rearrangement in breast cancer PD4 I I5a (Table I). A-to-I editing encoded by ADAR can lead to either enhanced or reduced virus growth and persistence depending upon the specific virus (Samuel 20I I). ADAR-I causes hypermutation of some RNA viruses such as HTLV-2 and STLV-3(Ko et 
al. 2012). The AID/APOBEC family of 7 proteins constitutes another innate antiretroviral defense system based on RNA editing. APOBEC4 is mutated in breast cancer PD4I09.

In Fig. 2, these recognition functions are extended to the recognition of viral RNA produced by transcription after DNA virus infections. In Fig. 2, PD3905a is shown as having a defect in detecting viral DNA. In PD3905a, the histone deacetylase 7 (HDAC7) gene is mutated. HDAC 7 was the most readily detected class II HDAC in an EBV producer and a non-producer cell line, suggesting involvement in repression during EBV latency (Bryant and Farrell 2002).

The presence of DNA anywhere other than the nucleus or mitochondria is perceived by the innate immune system as a Damage-Associated Molecular Pattern (DAMP) and triggers the assembly of an AIM2 inflammasome as a receptor for cytoplasmic DNA (Fig. 2). The AIM2 inflammasome activates inflammation and promotes maturation of inflammatory cytokines. AIM2 is mutated in breast cancer PD4086a but normal in other breast cancers. Fig. 2 also shows potential indirect actions of other mutations such as DSTYK (a caspase inducer) and CIQTNFI (a target of the inflammatory response mediator ILI $\beta$, Fig. 2 and Table I).

Autophagy. Figs. I-2 show 7 breast cancers with mutations in genes encoding or regulating autophagy functions (e.g. PD385 I a, PD3904a, PD3905a, PD4 I03a, PD4 I07a, PD4 I I6a, and PD4I20a). Autophagy ("self-eating") is a degradation process, in which abnormal cytoplasmic content is engulfed and degraded by the lysosome. Autophagy is also a notable pathway mediating innate immune responses that eliminate pathogens. A subset of viruses and bacteria subvert autophagic pathways to promote their own replication. The importance of autophagy in the cellular response is illustrated by the diversity of viruses - including HIV-I, influenza and herpes viruses - that can inhibit autophagy (Garcia-Sastre 20I3).

NF-kB responses. Nine breast cancers are shown with mutations affecting NF-kB signaling or its regulation (Figs. I- 2). Because of its extensive role in immune action, NF$\mathrm{kB}$ has been termed the central mediator of the immune response. Mutations in NF-kB pathways or their regulation may affect host response to breast cancer whatever its cause. Transcriptional regulators of the NF-kB/lkB family promote the expression of hundreds of target genes, markedly affecting the host immune response and cell cycle. These proteins include many cytokines and chemokines, receptors required for immune recognition, proteins involved in antigen presentation, adhesion receptors involved in transmigration across blood vessels walls, growth factors and proto-oncogenes. Relevant 
inducers are typically viruses, or other activators or mediators of innate immunity (Hiscott et al. 200I).

NF-kB regulation is influenced by many different genes and is abnormal in some breast cancers (Figs. I-2). For example, PD3904a has a mutation in RHEBLI (Yuan et al. 2005), a positive regulator of NF-kB signaling (Figs I-2 and Table I). Even mutations in other pathways can impact the activation of NF-kB. PD3890a and PD3904a have mutations within the NFAT pathway. The NFAT family of transcription factors regulates cytokine gene expression by binding to the promoter/enhancer regions of antigenresponsive genes, usually in cooperation with heterologous DNA-binding partners. In some systems, activation of NFAT and NF-kB are mutually dependent and even bind at the same promoter (Cai et al. 20 I la; Fu et al. 2006).

Mutations in proinflammatory NF-kB pathways can also contribute to human viral oncogenic transformation. Viral oncogene products, including human T-cell leukemia virus type I (HTLV-I) Tax protein and EBV latent infection membrane protein I, each act by distinct mechanisms to disrupt NF-kB regulation and initiate viral transformation (Hiscott et al. 200 I). Localization of NF-kB encoding genes at sites of chromosomal translocations and genomic rearrangements in cancer, high levels of NF-kB activity in many breast cancer cells, and constitutive nuclear NF-kB complexes in virally mediated Hodgkin's lymphoma cells all support viral participation.

Inflammatory cytokines and interferons. At least ten breast cancers show damage to genes essential for inflammatory cytokines (Figs. I-2, lower left) but this can occur in different ways. Damage to interferon inducible genes can also occur at multiple points but the result is to disable some aspect of interferon mediated protection (Figs I-2, lower right) or to change inflammatory processes, required for a proper adaptive immune response.

In the breast cancer PD4 I 07a genome, mutation of a single gene may affect several relevant functions at once. PPP2RIA gene mutations can deregulate NF-KB activation and IL-2 or IFN-Y production (Eitelhuber et al. 20I I). PD4 I07a also has a deletion in IL20RA and IL22RA2 which disables JAK-STAT signal transmission of interferon activities (Table I). Further illustrations of how mutations affect cytokine or interferon signaling are documented in Table I.

Colony stimulating factors. Colony-Stimulating Factor-I (CSF-I) and its receptor (CSF-IR) regulate macrophage production and mammary gland development. CSFs are in clinical trials as treatment for some types of cancer. CSFs can increase the 
production of complement components. Complement components are mutated in a few of the breast cancer genomes. In the 2 I breast cancers here, CSFs genes were normal but mutations in other genes could affect CSF expression. A tandem duplication in breast cancer PD4006a included YY2, a significant regulator of CSF3. In contrast, HAXI is essential for CSF-triggered granulopoiesis and a genetic defect in HAXI causes premature apoptosis of myeloid progenitor cells. HAXI is deleted in breast cancer PD4I09a.

Other mechanisms of interfering with the innate immune response not shown in Figs. $I$ and 2.

Figs. I-2 are based on basic outline models of innate immune response pathways (Mogensen 2009; Barber 20II) but many specific steps are omitted for clarity. The omitted specific steps provide further opportunities for mutations in additional genes to interfere with the immune response (e.g. DSTYK and CIQTNFI in Fig 2). These mutations may affect response to other pathogens, other innate immunity receptors or pathways, damage connections between innate and adaptive immunity or dysregulate the response.

Examples of mutation in other pathogen associated molecular patterns (PAMPs). Receptors for pathogen-associated molecular patterns are pattern recognition receptor proteins that occur outside the cell, in the cytoplasm, or in the nucleus. PAMPs can be associated with microbial pathogens or cellular stress.

In breast cancers PD3904a and PD4 I 20a, the gene encoding a pattern recognition scavenger receptor CDI63LI is mutated (Table I). Generally this may encourage further mutations because scavenger receptors are essential to remove waste or harmful substances. Cysteine-rich scavenger receptors can serve as pattern recognition receptors for bacteria and for hepatitis C virus (69). The DSCAM gene, involved in a rearrangement in PD4088a (Table I) encodes a pattern recognition receptor that can produce thousands of is oforms via mutually exclusive alternative splicing, i.e. a cloud of different immune effectors with different specificities (Ziauddin and Schneider 20I2).

\section{Breast cancer gene mutations can interfere with connections to adaptive} immunity. PD4 194a contains a mutation in the gene encoding E-cadherin / CDHI (Table I). A common feature shared between several putative human cancer-associated viruses, such as EBV, HBV, HCVs, and HPV is the ability to reduce the expression of cellular Ecadherin. Of the common tumor viruses, HPVI6 is highly efficient at reducing E-cadherin levels. Mutation of the E-cadherin gene may affect the efficiency of the immune response (Laurson et al. 2010) but E-cadherin is not shown in Figs. I-2. 
ARID2 is mutated in the BRCAI associated breast cancer PD3905. ARID2 encodes a part of a chromatin remodeling complex and is not indicated in Figs. I-2. Infected host cells harboring ARID2 mutations may have lost their ability to express higher levels of class I MHC molecules in response to IFN, making them less visible to cytotoxic T lymphocytes (Zhao et al. 20I I; Li et al. 20I I).

\section{Mutations in genes encoding unclassified proteins related to viral}

\section{infections: Selection for or against different infections by breast gene}

mutations. Because different viruses require different sets of host cellular genes in order to infect and proliferate, mutation of cellular genes in breast cancers can alter targets that affect susceptibility to viral infections. Some of these targets are not clearly linked to innate immunity. In breast cancer PD3905a, SLC48A8 is mutated. SLC48A8 mRNA levels are decreased by antisense transcripts from LTR promoter elements of human endogenous retroviruses. In PD4 I07a mutation of may protect against entry of several $\alpha$ herpesviruses, because the PVRLI protein mediates their entry.

There are many similarities, but surface proteins from different viruses can induce differences in host chemokines and cytokines (Mogensen and Paludan 200 I). The secreted protein TGF- $\beta 2$ (deleted in PD4088a), has a major effect on IgA production from adjacent plasma cells. Deletion of ATP7IP makes EBV lytic activation unlikely (Chang et al. 2005), but ARHGDIB is a lymphoid-specific intrinsic negative regulator of HIV-I replication (Watanabe et al. 20I2). Similarly desmoglein 2 (DSG2) acts as a high affinity receptor for human adenoviruses, so DSG2 mutation in PD4 I 20a would argue against adenovirus infections.

\section{Tandem Duplications can favor or suppress some infections}

In the PD4006a breast cancer, a tandem duplication on chromosome 17 from bases 44,093,205 to 46, I 76,285 includes MIRI52. MIRI52 overexpression inhibited production of cytokines, and may participate in fine tuning the innate immune response (Liu et al. 2010). In breast cancer PD3945a, a tandem duplication of about I million bases on chromosome 2 (positions $69,554,984$ to 70,626,823) could theoretically alter susceptibility to some infections. MXDI is also encoded in the duplicated region and MXDI protein product can participate in repressing EBV latent membrane protein I (Jansson et al. 2007) MXDI also antagonizes the effects of c-Myc, a transcription factor whose activity is frequently elevated in cancer. Myc can impose a non-immunogenic phenotype in virally infected cells (Staege et al. 2002). 
In the PD385 I a breast cancer, a tandem duplication contains genes that may represent bolstered immune defenses. For example, the ZBPI gene product suppresses HSV-I growth. This suppression is independent of DNA sensing through mechanisms involving suppression of viral genomes (Pham et al. 2013). ZBPI also has other activities. ZBPI decreases cancer cell migration and metastatic proliferation. In breast cancer PD4086a, an intrachromosomal tandem duplication involves the PTPNI gene. PTPNI negatively regulates MyD88 and TRIF dependent proinflammatory cytokine and type I IFN production (Figs I- 2).

Many other tandem duplications only involve part of a gene sequence involved in immunity. This may alter the regulation, tissue specific expression or affect functions.

\section{Independent Supporting Evidence}

In at least five different sporadic breast cancers with normal BRCAI and BRCA2 genes, there are mutations related to pathways depending on $\mathrm{BRCAI} / 2$ gene products (PD4088a, PD4 103a, PD4 109a, PD4 I20a, and PD4/ 98a). Mutations of genes encoding proteins within this pathway are independently known to favor some viral infections. HPV proteins $\mathrm{E} 6$ and $\mathrm{E7}$ interact with BRCAI and BRCAI and BRCA2 gene mutations increase risk for cervical cancer (caused by HPV's) (Zhang et al. 2005; Friedenson 20 I 0b, c). Other related gene mutations cause hereditary conditions with proven increases in susceptibility to specific sets of infections and cancers. Three connections are specific to breast cancers with mutations in the DNA damage response pathway dependent on BRCAI and BRCA2. Two of these mutations are found in PD4 103 a (e.g. FANCB and NBN)(Lowy and Gillison 2003; Spardy et al. 2007; Gregorek et al. 2010). PD4198a shows a different connection because it contains an ATM mutation. ATM participates in the DNA damage response affecting both the immune system and breast cancer risk. The DNA damage response may also participate in alerting the immune system to the presence of potentially dangerous cells (Gasser et al. 2005)

\section{Acquired immunodeficiency states reactivate or stimulate known}

cancer viruses. Immune system dysfunctions that favor infections are well known. Suppression of the immune system before kidney transplantation increases risks for breast and three other cancers (Hibberd et al. 2013). Recipients have a well-documented increased incidence of human HPV related malignancies. Nearly $50 \%$ of male kidney transplant recipients were positive for HPV sequences, most often the carcinogenic HPVI6 genotype (Tornesello et al. 2010). Systemic immunosuppression is associated with cervical cancer disease progression (Kosmaczewska et al. 2012). Lymphomas undergo 
spontaneous remission after immunosuppression is withdrawn (Vesely et al. 20 I I). AIDS patients have greatly increased risks for herpes viral Kaposi's sarcoma and for cervical cancer. Paradoxically, breast and ovarian cancer risks sometimes seem reduced (Frisch et al. 200I). Immune responses weakened or dysregulated in AIDS patients might be sources of breast cancer cell progression. Alternatively, antiretroviral therapy for AIDS may reduce breast/ovarian cancer risks but this is still unclear. Seemingly reduced breast cancer risk in transplant patients may reflect screening- (Engels et al. 20 I I) or sampling artifacts or increased mortality. Transplant patients with prior breast cancers had a HR > 5 times cancer specific mortality (Brattstrom et al. 20l3). The immune system is essential to control EBV latent infection. Individuals with a congenital or acquired immune deficiency have increased risks for EBV-associated diseases, which vary according to the type and the severity of immunodeficiency. Lupus patients have increased risks for several malignancies. Chronic immunosuppressive drug treatment is a widely suspected risk factor.

\section{Hereditary immunodeficiency diseases are susceptible to specific} infections because of mutations related to those found in breast cancers. Absence of TLR3 signaling increases susceptibility to HSV-I infection. Mutations in 3 proteins in the TLR signaling pathway have been linked to herpes simplex encephalitis (HSE) in children. Mutations in NEMO (NF-kB Essential Modulator) (Figs I, 2) predispose primarily to infections with herpes viruses. Other primary immunodeficiencies predispose to severe infections with human papilloma viruses (Dropulic and Cohen 20I I).

Most if not all endogenous retroviruses are inactivated by mutation or other mechanisms but they may become reactivated by immunodeficiency. In immunodeficient mice, active retroviruses can re-emerge through recombination to cause diseases that include cancer (Young et al. 2012). TLR3 or TLR7 deficient animals are susceptible to certain infections but remained capable of producing type I IFN in response to RNA species (Barber 20 I I). Dozens of studies find immunodeficient mice have increased susceptibility to spontaneous tumors. Their susceptibility to carcinogen induced cancers can depend on the immune deficit, the cancer site, and the carcinogen (Vesely et al. 20 I I).

Functional consequences of mutations. Deletion or breakage and rearrangement either eliminates or drastically changes gene function and many smaller mutations such as frame shifts can cause major losses in protein function. Here, high percentages of mutations are complete or partial gene deletions or rearrangements. For example, in breast cancer PD4 103a, 16I different genes were either deleted or disrupted 
by DNA breakpoints and involved a deletion of 5-7 million bases. An additional 47 coding genes had one or more base changes, small insertions or deletions. $4 \mathrm{I}$ of 47 mutations in coding genes changed an amino acid in the protein product. In the remaining 6 coding mutations, transcription factor binding, gene regulation, splicing, and other interactions could all be changed. From the total of 208 deletion or coding gene mutations $(16 \mid+47)$, only about 160 genes had usable functional information available.

In breast cancer PD4 I03a, virtually every one of the 160 mutations occurred in innate immunity or in metabolic pathways typically targeted by viruses (unpublished). Beyond the mutation and dysregulation in innate immunity, viruses typically disable or hijack many other host functions such as translation, calcium signaling, cell morphology, etc. Profound alterations in metabolism can accompany infection, resulting in benefits to the pathogen at host expense. Breast cancer PD4 I 03a had these kinds of profound pathogen favoring alterations in metabolism. Many mutations in a cancer cell subclones may evolve to become fixed because they give the cancer or cancer pathogen some sort of advantage and are compatible with what is left of the immune response. However, the functional effects of most gene mutations were not directly measured in breast cancer cells. Functional effects of epigenetic changes, very large breakages and duplications (>about 7.5 Mb), mutations in many RNA encoding genes, mutations in inter- and intragenic sequences, could not be confidently evaluated. Moreover useful functional information for many genes does not exist and is urgently needed.

\section{Conclusions and implications}

Breast cancer mutations cripple the ability of the immune system to prevent or restrain cancer causing infections, to remove cells damaged by infection and to regulate inflammation. Large increases in cancer risks in immune compromised patients support the idea that accumulation of immune deficits by mutation would activate indolent cancers.

Mutations in immunity may also increase cancer risks by dysregulating responses to breast cancer with or without antigen or pathogen exposure. Mutational damage and dysregulation in the immune system and inflammatory processes also represent significant additional variables that can confound studies of viral associations with breast cancers. 
The exact individual mutations potentially affecting immune responses are vastly different when one breast cancer is compared to another. Each breast cancer also has a different deficit in immunity or its regulation. Each breast cancer may differ in susceptibility to a range of carcinogenic infections. Different infections can trigger different immune responses. Thus mutational loss of a different set of genes in each breast cancer environment changes which infections are more likely to survive. Loss or damage to specific host gene products required by some infections restricts their likelihood. Comparisons of Figs I-2 reflect shared innate immune signal transmission pathways, so damage to shared pathways may increase the likelihood of cancer related infections in general.

Acquired defects in innate and adaptive immunity explain how many viruses have the potential to cause cancer but only in the right host. A common virus infection such as $E B V$ is present in most people, but EBV causes cancers only rarely because most people do not have mutations that cripple the immune system genes that prevent EBV associated cancers. Genomic data does not tell which infections underlie or accompany breast cancers.

The absence of a consistent mutational profile found here stresses the need for personalized breast cancer genomic information in preventing and treating breast cancer. This is probably already feasible because of rapid precipitous declines in costs which are ongoing. Different therapeutic rationales can be envisioned but they should be based on personal breast cancer genomic information. Perhaps specific defects or dysregulation in the acute immune response can be compensated for rather than suffer further damage as a side effect of therapy. Based on genomic information, vaccines, anti-viral and/or NF-kB inhibitory drugs might have wide utility in treating or preventing recurrence of breast cancers. Several oncolytic viral therapies depend on the idea that tumor cells acquire mutations that inactivate interferon signaling. ThI cytokines such as interferon gamma and TNF can directly induce permanent growth arrest, i.e. cellular senescence, in murine and human cancers. During mutagenesis, the inhibition of inflammasomes and products such as ILI $\beta$ (PD4 I I5a) and caspases (PD4088a) have profound effects on carcinogenesis and tumor progression (Rathinam et al. 20I2). 
Tissue specificity. The working model here is that cancer occurs in a specific tissue because immune compromise or dysregulation accompany mutational events there (e.g. from carcinogen exposures). Mutations activate infections or cause unregulated inflammation in the tissue. Thus inheriting a defect in BRCAI or BRCA2 "breast cancer genes" should increase cancer risks not just in breast or ovary but at any site where further mutations accompany infection/inflammation. Much data supports the idea a defective BRCA gene does not cause breast cancer by itself and shows that other organs can also become susceptible, with increased risks for infection associated cancers (Friedenson 2010a, 2007). The extent of DNA damage strongly depends on exposure to particular types of mutagens such as those that cross link DNA (Levin et al. 2012). Biallelic mutations in BRCA2 or in its binding partner PALB2 are strongly associated with early childhood cancers including leukemias, medulloblastomas, Wilms tumors and neuroblastoma (Wagner et al. 2004; Reid et al. 2007), all occurring well before breast cancers.

Role in other cancers. Homozygous deletions in chromosome $9 p$ include a large cluster of interferon genes and this deletion has been reported in acute lymphoblastic leukemia, gliomas and at a lower frequency in lymphomas, melanomas, lung cancers, other solid tumors. Homozygous deletions of the short arm of chromosome 9 occur in ovarian adenocarcinoma cell lines and loss of heterozygosity occurs in sporadic tumors (Chenevix-Trench et al. 1994). Breast cancer PD4088a lost this area as part of a large deletion on chromosome 9. Defensins are microbiocidal peptides within the innate immune system that are active against enveloped viruses, bacteria, and fungi. A deletion in the defensin gene DEFBI 27 occurs in one of the breast cancers (PD4 199a) and a homozygous deletion involving defensins occurs in other cancers. These deletions suggests that the loss of immune or viral defenses occurs broadly in cancers. The arguments here are also consistent with contributions from other types of microbial infections to cancer in general. For example gastric cancer and gastric MALT lymphoma are associated with Helicobacter pylori infection.

\section{Figure Legends}


Fig. I Defects in signaling pathways mediated by TLR3 and TLR7 as examples of disruption of innate immunity to RNA viruses in breast cancers. Because only an outline of the pathway is shown, many interactions are indirect. Approximate points in the signaling pathway outline that show mutations, deletions or rearrangements are indicated with the name of the breast cancer in which they occur. Although different genes are damaged, there are similar impairments in overall functions so that the end result would presumably be an impaired or dysregulated immune response. Multiple defects in initial recognition of RNA viruses are indicated on the Figure. STING facilitates RIG-I signaling (see also Fig. 2). The end steps in these pathways involve the nucleus and are largely shared in Fig. 2 but the exact genes mutated may differ. The basic pathways shown are based on Mogenson (Mogensen 2009) and Barber (Barber 20II)

Fig. 2 Defects in signaling pathways in breast cancers that disrupt or dysregulate innate immunity to DNA viruses. Defects in genes essential for viral recognition are shown next to the depiction of a DNA virus. The mechanisms for immediate recognition of viral RNA or DNA via the STING pathway are not characterized. The basic pathways shown are based on Mogenson (Mogensen 2009) and Barber (Barber 20I I). The breast cancers in the gray box have mutations in genes which affect susceptibility to some viral infections (Table 2) but the genes have not been clearly linked to immunity. The figure shows potential indirect actions of other mutations such as DSTYK (a caspase inducer) and CIQTNFI (a target of ILI $\beta$ ). 


\section{Tables}

\section{Table I Common functions essential for immune responses are disabled by mutations in a variety of genes in different breast cancer genomes (Figs I and 2)}

\begin{tabular}{|c|c|c|}
\hline $\begin{array}{l}\text { Immune } \\
\text { function }\end{array}$ & $\begin{array}{l}\text { Breast } \\
\text { cancer }\end{array}$ & Example(s) of mutated gene (symbol) that negatively effects immune function: explanation and reference \\
\hline \multirow{8}{*}{$\begin{array}{l}\text { RNA virus } \\
\text { recognition }\end{array}$} & PD3890a & HUWE1: Novel cellular interactor of Gag-Pol through integrase binding (Yamamoto et al. 2011). \\
\hline & PD3904a & $\begin{array}{l}\text { IFIT1, IFIT2, IFIT1B, IFIT5: Antiviral innate immunity relies on the recognition of microbial structures. One such } \\
\text { structure is viral RNA that carries a triphosphate group on its } 5 \text { terminus (PPP-RNA). On the basis of this } \\
\text { specificity and the great abundance of IFIT proteins after infection, it has been proposed that the IFIT complex } \\
\text { antagonizes viruses by sequestering specific viral nucleic acids such as PPP-RNA (Pichlmair et al. 2011). C163L1: } \\
\text { scavenger receptor }\end{array}$ \\
\hline & PD4006a & FKBP8/FKBP38: T cell activation. \\
\hline & PD4107a & DROSHA: Silences endogenous retroviruses and HTLV-1 (Van Duyne et al. 2012) \\
\hline & PD4109a & $\begin{array}{l}\text { APOBEC4: The human APOBEC3 gene family on chromosome } 22 \text { encodes for } 7 \text { cytidine deaminases (A3A to A3H), } \\
\text { some with potent antiretroviral activity against retroviruses such as HTLV-1(ROGOZIN ET AL. 2005). }\end{array}$ \\
\hline & PD4115a & ADAR: Adenosine deaminase functions to modify viral RNA genomes. \\
\hline & PD4116a & RNASEH2C: Cleaves ribonucleotides from RNA-DNA duplexes. \\
\hline & PD4120a & DHX58: Pathogen recognition receptor for HCV \\
\hline \multirow{10}{*}{$\begin{array}{l}\text { DNA virus } \\
\text { recognition, } \\
\text { response, } \\
\text { inhibition }\end{array}$} & PD3905a & $\begin{array}{l}\text { HDAC7: HDAC } 7 \text { was the most readily detected class II HDAC in Akata and Raji cells, suggesting that it may be } \\
\text { involved in repression during EBV latency (Bryant and Farrell 2002). Toll-like receptors (TLRs) were reported to be } \\
\text { inhibited by HDAC inhibitors (Bode et al. 2007). }\end{array}$ \\
\hline & PD4006a & $\begin{array}{l}\text { MSN (moesin): T-cell activation, antigen recognition. Contains a T-cell receptor responsive site. PKD2: T cell } \\
\text { antigen receptor signaling (Navarro et al. 2012) }\end{array}$ \\
\hline & PD4086a & $\begin{array}{l}\text { AIM2: Absent in melanoma } 2 \text { (AIM2) is a double-stranded DNA receptor, and its activation initiates an } \\
\text { interleukin-1 beta processing inflammasome. AIM2 is implicated in host defense against several pathogens by } \\
\text { responding to cytoplasmic double stranded DNA and double stranded DNA vaccinia virus. (de Koning et al. 2012) }\end{array}$ \\
\hline & PD4088a & $\begin{array}{l}\text { DSCAM: pattern recognition receptor that (in drosophila) can produce thousands of isoforms via mutually } \\
\text { exclusive alternative splicing (Ziauddin and Schneider 2012). A cloud of different immune effectors with different } \\
\text { specificities. DSTYK: Caspase inducer. }\end{array}$ \\
\hline & PD4103a & $\begin{array}{l}\text { GATA3: critical early regulator of innate lymphoid cell development, thereby extending the paradigm of Gata3- } \\
\text { dependent control of type } 2 \text { immunity to include both innate and adaptive lymphocytes (Klein Wolterink et al. } \\
\text { 2013). GATA3 also interacts with HPV16, } 18 \text { control regions. NBN: NibrinNBS1/ p95 protein of MRE11/Rad50 } \\
\text { complex. Complex responds to ds DNA viruses such as adenovirus. PARG: inhibition avoids death of HSV-1 virally } \\
\text { infected cell (Grady et al. 2012) }\end{array}$ \\
\hline & PD4115a & $\begin{array}{l}\text { SREBP2: Host defense against viral infection (CMV model) involves IFN mediated down-regulation of sterol } \\
\text { biosynthesis. Lowered cholesterol protects against viral infection (Blanc et al. 2011) C1QTNF1: target of IL-1 beta }\end{array}$ \\
\hline & PD4116a & BANF1 (BAF): acts as a potent host defense against poxviral DNA replication in the cytoplasm(Ibrahim et al. 2011) \\
\hline & PD4120a & $\begin{array}{l}\text { GATA3: Critical early regulator of innate lymphoid cell development, thereby extending the paradigm of Gata3- } \\
\text { dependent control of type } 2 \text { immunity to include both innate and adaptive lymphocytes (Klein Wolterink et al. } \\
\text { 2013). GATA3 also interacts with HPV16, } 18 \text { control regions. }\end{array}$ \\
\hline & PD4198a & $\begin{array}{l}\text { ATM: required to control EBV and other gamma herpesviruses (Kulinski et al. 2012). ATM knockdown activates } \\
\text { cells of the innate immune system. The DNA damage response may also participate in alerting the immune } \\
\text { system to the presence of potentially dangerous cells (Gasser et al. 2005) }\end{array}$ \\
\hline & PD4199a & DEFB127: Beta defensin \\
\hline
\end{tabular}




\begin{tabular}{|c|c|c|}
\hline \multirow{8}{*}{ Autophagy } & PD3851a & STX4: lysosome exocytosis \\
\hline & PD3904a & $\begin{array}{l}\text { FYCO1: Autophagy protein. A subset of viruses and bacteria subvert autophagic pathways to promote their own } \\
\text { replication (Pankiv and Johansen 2010) }\end{array}$ \\
\hline & PD3905a & VAMP7: Autophagy TMEM74: regulates autophagy \\
\hline & PD4103a & PHLDA1: Mediates and positively regulates both autophagy and apoptosis pathways \\
\hline & PD4107a & $\begin{array}{l}\text { BCLAF1: inhibits transformation by adenovirus. Caspase- } 10 \text { inhibits autophagy by cleaving the BCL2-interacting } \\
\text { protein BCLAF1, itself a strong inducer of autophagy that acts by displacing beclin-1 from BCL2 (Lamy et al. 2013). }\end{array}$ \\
\hline & PD4116a & KAT5: Regulates autophagy LYST: Lysosomal trafficking regulator \\
\hline & PD4120a & STX7: Ordered fusion of endosomes and lysosomes with the phagosome \\
\hline & PD4248a & STX7: Ordered fusion of endosomes and lysosomes with the phagosome \\
\hline \multirow[t]{9}{*}{$\begin{array}{l}\text { IFN inducer, } \\
\text { IFN inducible }\end{array}$} & PD3890a & COL1A2: repressed by RFX in presence of IFN- $\gamma$ (Sengupta et al. 2005) \\
\hline & PD3904a & $\begin{array}{l}\text { MARCH5, TANK: Mitochondrial ubiquitin ligase MARCH5 promotes TLR7 signaling by attenuating TANK action (Shi } \\
\text { et al. 2011) }\end{array}$ \\
\hline & PD3905a & $\begin{array}{l}\text { HMGA1: controls IFN } \gamma \text { gene expression (Chau et al. 2005). PACSIN1: regulates the TLR7/9-mediated type I IFN } \\
\text { response in plasmacytoid dendritic cells (Esashi et al. 2012) }\end{array}$ \\
\hline & PD3945a & PCBP1 Gene duplication: Down regulates type 1 IFN, positively modulates CSFV growth (Li et al. 2013) \\
\hline & PD4005a & $\begin{array}{l}\text { TRAF3: TRAF3 functions downstream of TLR3,7 in the cytoplasm and leads to production of type I IFNs and activates } \\
\text { NF-KB. }\end{array}$ \\
\hline & PD4107a & $\begin{array}{l}\text { EYA4: stimulates IFN beta, enhances innate immune response against viruses. IFNGR1: crucial roles in regulating } \\
\text { both innate and adaptive immunity, anti-proliferative. }\end{array}$ \\
\hline & PD4115a & $\begin{array}{l}\text { SREBP2: Host defense against viral infection (CMV model) involves IFN mediated down-regulation of sterol } \\
\text { biosynthesis. Lowered cholesterol protects against viral infection (Blanc et al. 2011) TRAF3: TRAF3 functions } \\
\text { downstream of TLR3,7 in the cytoplasm and leads to production of type I IFNs and also activates NF-kB }\end{array}$ \\
\hline & PD4120a & IFNA2: $\alpha$ IFN antiviral. Gbf1: induced by IFN $\gamma$ \\
\hline & PD4199a & AEN: IFN stimulated exonuclease gene required for $\mathrm{p} 53$ dependent apoptosis \\
\hline \multirow[t]{9}{*}{$\begin{array}{l}\text { NF-kB } \\
\text { responses }\end{array}$} & PD3890a & $\begin{array}{l}\text { NFATC1: The NFAT family of transcription factors regulates cytokine gene expression by binding to the } \\
\text { promoter/enhancer regions of antigen-responsive genes, usually in cooperation with heterologous DNA-binding } \\
\text { partners. SUMO4: Negatively regulates NF-kB }\end{array}$ \\
\hline & PD3904a & $\begin{array}{l}\text { USP6 Activates NFKB pathway (Pringle et al. 2012). NFATC1: The NFAT family of transcription factors regulates } \\
\text { cytokine gene expression by binding to the promoter/enhancer regions of antigen-responsive genes, usually in } \\
\text { cooperation with heterologous DNA-binding partners. RHEBL1: positive regulator of NFKB signaling (Yuan et al. } \\
\text { 2005) }\end{array}$ \\
\hline & PD3905a & RHEBL1: positive regulator of NF-kB signaling (Yuan et al. 2005) \\
\hline & PD4006a & NFKB1: Sign of Inflammation. Stimulated as a result of TLR binding viral products (Lin et al. 2012) \\
\hline & PD4107a & RPS6KA3: NFKB gene expression. TBK1: regulates I-kappa-B-kinases and CD8+ T-cell induction \\
\hline & PD4109a & ITGB1: Activates NF-kB signaling; involved in inflammation \\
\hline & PD4116a & $\begin{array}{l}\text { NFKB1E: persistent stimulation of T cells, monocytes, or fibroblasts with TNFA resulted in the coordinated } \\
\text { degradation, synthesis, and localization of IKBA, IKBB, and IKBE necessary to generate the characteristic NFKB } \\
\text { activation profile RELA: NF-KB response }\end{array}$ \\
\hline & PD4120a & CARD11: induces NFKB activity \\
\hline & PD4248a & $\begin{array}{l}\text { BIN1: loss elevates NF-kB-dependent expression of IDO, driving escape of oncogenically transformed cells from T } \\
\text { cell-dependent antitumor immunity(Muller et al. 2005) }\end{array}$ \\
\hline
\end{tabular}




\begin{tabular}{|c|c|c|}
\hline $\begin{array}{l}\text { Proinflam- } \\
\text { matory } \\
\text { cytokines }\end{array}$ & PD3851a & COQ7: elevated inflammatory cytokines (Wang et al. 2010) \\
\hline & PD3904a & $\begin{array}{l}\text { NOS2: In the absence of NOS2 activity, IL12 did not stimulate NK cells for cytotoxicity or interferon-gamma } \\
\text { release, and failed to activate TYK2 and to tyrosine-phosphorylate STAT4, the central signal transducer of IL12, in } \\
\text { NK cells. NOS2-derived NO is a prerequisite for cytokine signaling and function in innate immunity. }\end{array}$ \\
\hline & PD3905a & DAZAP2: regulation of IL17RB (Popova et al. 2012), recruiting monocytes and neutrophils to site of inflammation \\
\hline & PD4085a & $\begin{array}{l}\text { ETS1: ETS1 regulates a broad gene expression program in NK cells that promotes target cell recognition while } \\
\text { limiting cytokine-driven activation (Ramirez et al. 2012) }\end{array}$ \\
\hline & PD4103a & $\begin{array}{l}\text { IL33: a member of the IL1 family that potently drives production of T-helper-2 Th2 associated cytokines e.g. IIL. } \\
\text { GIT2: regulates chemokine mediated motility of thymocytes (Phee et al. 2010). NAMPTL: Pleotropic enzyme } \\
\text { adipocytokine, growth factor and cytokine; regulation of tumor promoting inflammation, blocks NAD synthesis. }\end{array}$ \\
\hline & PD4107a & IL21R: Receptor for interleukin (IL)-21, a novel cytokine with anti-tumor effects. \\
\hline & PD4109a & $\begin{array}{l}\text { INPP5D: Innate immunity modulating cytokine signaling within the hematopoietic system. C1QTNF6: stimulates } \\
\text { stat3 and NFKB pathways novel inflammatory regulator Decrease expression of IL10, a potent anti-inflammatory } \\
\text { cytokine that modulates inflammatory signaling pathways }\end{array}$ \\
\hline & PD4115a & $\begin{array}{l}\text { OSMR: IL-31 (a member of the IL- } 6 \text { family of cytokines) signals through a hetero-dimer receptor composed of } \\
\text { OSMR and IL-31RA, a complex that stimulates the JAK-STAT, the RAS/ERK and the PI3K/AKT signal transduction } \\
\text { pathways. SOC6: suppressor of cytokine signaling }\end{array}$ \\
\hline & PD4120a & $\begin{array}{l}\text { IL1A: proinflammatory cytokine. CISH: cytokine inducible -SH containing protein. Negative regulator for } \\
\text { inflammatory signaling. }\end{array}$ \\
\hline & PD4192a & $\begin{array}{l}\text { SPP1 (osteopontin) : an inflammatory cytokine associated with Th17-related pathologies (Sarkis et al. 2013). } \\
\text { SPP1 appears to have a role in macrophage infiltration, among other functions (Bauer et al. 2009) Upregulated on } \\
\text { pneumocystis infection in AIDS patients }\end{array}$ \\
\hline
\end{tabular}

Table 2 Breast cancer mutations not clearly linked to innate immunity affecting viral infections

\begin{tabular}{|l|l|}
\hline PD3905a & $\begin{array}{l}\text { RPS10: Interacts with HIV-1 Nef to impair translation (Abbas et al. 2012). SLC4A8: antisense transcripts formed from LTR } \\
\text { promoter elements of HERVs decrease mRNA levels of SLC4A8 (Gogvadze et al. 2009). CCNT1: Interacts with HIV-1 Tat protein. }\end{array}$ \\
\hline PD4006a & NHP21L: May be involved in regulating replication of retroviral elements (Li et al. 2012) \\
\hline PD4116a & $\begin{array}{l}\text { VPS37B: Functions in sorting ubiquitylated protein cargoes into multivesicular bodies, mediates receptor down regulation. Part of } \\
\text { ESCRT-I complex required for HIV-1 budding and infectivity and virion release. }\end{array}$ \\
\hline PD4199a & BEND4: Possible role in organizing viral DNA during replication or transcription. \\
\hline
\end{tabular}

\section{References}

Abbas W, Dichamp I, Herbein G (20I2) The HIV-I Nef protein interacts with two components of the $40 \mathrm{~S}$ small ribosomal subunit, the RPSI0 protein and the I8S rRNA. Virology journal 9:103. doi:10.1 I86/1743-422X-9-103

\section{Abbas YM, Pichlmair A, Gorna MW, Superti-Furga G, Nagar B (20I3) Structural basis for viral 5'- PPP-RNA recognition by human IFIT proteins. Nature 494 (7435):60-64. doi:10.1038/nature II 783}

Barber GN (20I I) Innate immune DNA sensing pathways: STING, AIMII and the regulation of interferon production and inflammatory responses. Current opinion in immunology 23 (I):10-20. doi:10.1016/j.coi.2010.12.015 
Bauer AK, Fostel J, Degraff LM, Rondini EA, Walker C, Grissom SF, Foley J, Kleeberger SR (2009) Transcriptomic analysis of pathways regulated by toll-like receptor 4 in a murine model of chronic pulmonary inflammation and carcinogenesis. Molecular cancer 8:107. doi:I0.1 I86/1476-4598-8-107

Bernardo AR, Cosgaya JM, Aranda A, Jimenez-Lara AM (20/3) Synergy between RA and TLR3 promotes type I IFN-dependent apoptosis through upregulation of TRAIL pathway in breast cancer cells. Cell death \& disease 4:e479. doi:10.1038/cddis.2013.5

Bidwell BN, Slaney CY, Withana NP, Forster S, Cao Y, Loi S, Andrews D, Mikeska T, Mangan NE, Samarajiwa SA, de Weerd NA, Gould J, Argani P, Moller A, Smyth MJ, Anderson RL, Hertzog PJ, Parker BS (20I2) Silencing of Irf7 pathways in breast cancer cells promotes bone metastasis through immune escape. Nature medicine 18 (8). doi: 10.1038/nm.2830

Blanc M, Hsieh WY, Robertson KA, Watterson S, Shui G, Lacaze P, Khondoker M, Dickinson P, Sing G, Rodriguez-Martin S, Phelan P, Forster T, Strobl B, Muller M, Riemersma R, Osborne T, Wenk MR, Angulo A, Ghazal P (20II) Host defense against viral infection involves interferon mediated down-regulation of sterol biosynthesis. PLoS biology 9 (3):el 000598. doi:10.137I/journal.pbio. 1000598

Bode KA, Schroder K, Hume DA, Ravasi T, Heeg K, Sweet MJ, Dalpke AH (2007) Histone deacetylase inhibitors decrease Toll-like receptor-mediated activation of proinflammatory gene expression by impairing transcription factor recruitment. Immunology 122 (4):596-606. doi:10.1 I I I/j.1365-2567.2007.02678.x

Brattstrom C, Granath F, Edgren G, Smedby KE, Wilczek HE (2013) Overall and Cause-Specific Mortality in Transplant Recipients with a Pretransplantation Cancer History. Transplantation 96 (3):297-305. doi: 10.1097/TP.0b0 I 3e3 I829854b7

Bryant H, Farrell PJ (2002) Signal Transduction and Transcription Factor Modification during Reactivation of Epstein-Barr Virus from Latency. Journal of virology 76 (20): 10290-10298

Cai T, Li X, Ding J, Luo W, Li J, Huang C (20 I l a) A cross-talk between NFAT and NF-kappaB pathways is crucial for nickel-induced COX-2 expression in Beas-2B cells. Current cancer drug targets II (5):548-559

Cai Z, Sanchez A, Shi Z, Zhang T, Liu M, Zhang D (20l lb) Activation of Toll-like receptor 5 on breast cancer cells by flagellin suppresses cell proliferation and tumor growth. Cancer research 7I (7):2466-2475. doi:I0.I I58/0008-5472.CAN-I0-I993

Campbell MJ, Scott J, Maecker HT, Park JW, Esserman LJ (2005) Immune dysfunction and micrometastases in women with breast cancer. Breast cancer research and treatment 91 (2): I63-I7I. doi: I0.1007/s 10549-004-7048-0

Chang LK, Chung JY, Hong YR, Ichimura T, Nakao M, Liu ST (2005) Activation of Sp I-mediated transcription by Rta of Epstein-Barr virus via an interaction with MCAFI. Nucleic acids research 33 (20):6528-6539. doi:10.1093/nar/gki956

Chau KY, Keane-Myers AM, Fedele M, Ikeda Y, Creusot RJ, Menozzi L, Cousins DJ, Manfioletti G, Feigenbaum L, Fusco A, Ono SJ (2005) IFN-gamma gene expression is controlled by the 
architectural transcription factor HMGAI. International immunology 17 (3):297-306. doi:10.1093/intimm/dxh209

Chenevix-Trench G, Kerr J, Friedlander M, Hurst T, Sanderson B, Coglan M, Ward B, Leary J, Khoo SK (1994) Homozygous deletions on the short arm of chromosome 9 in ovarian adenocarcinoma cell lines and loss of heterozygosity in sporadic tumors. American journal of human genetics 55 (I): I43-I49

Cunningham-Rundles S, Filippa DA, Braun DW, Jr., Antonelli P, Ashikari H (1981) Natural cytotoxicity of peripheral blood lymphocytes and regional lymph node cells in breast cancer in women. Journal of the National Cancer Institute 67 (3):585-590

Curigliano G (20 I I) Immunity and autoimmunity: revising the concepts of response to breast cancer. Breast 20 SuppI 3:S7I-74. doi:10.10I6/S0960-9776(II)70298-3

de Koning HD, Bergboer JG, van den Bogaard EH, van Vlijmen-Willems IM, Rodijk-Olthuis D, Simon A, Zeeuwen PL, Schalkwijk J (20I2) Strong induction of AIM2 expression in human epidermis in acute and chronic inflammatory skin conditions. Experimental dermatology 21 (I2):96I-964. doi:10.1 I I I/exd. 12037

Dropulic LK, Cohen JI (20II) Severe viral infections and primary immunodeficiencies. Clinical infectious diseases : an official publication of the Infectious Diseases Society of America 53 (9):897-909. doi: 10.1093/cid/cir610

Ehsan N, Murad S, Ashiq T, Mansoor MU, Gul S, Khalid S, Younas M (20I3) Significant correlation of TLR4 expression with the clinicopathological features of invasive ductal carcinoma of the breast. Tumour biology : the journal of the International Society for Oncodevelopmental Biology and Medicine. doi: 10.1007/s I 3277-013-0645-y

Eitelhuber AC, Warth S, Schimmack G, Duwel M, Hadian K, Demski K, Beisker W, Shinohara H, Kurosaki T, Heissmeyer V, Krappmann D (20II) Dephosphorylation of Carma I by PP2A negatively regulates T-cell activation. The EMBO journal 30 (3):594-605.

doi:10.1038/emboj.2010.331

Engels EA, Pfeiffer RM, Fraumeni JF, Jr., Kasiske BL, Israni AK, Snyder JJ, Wolfe RA, Goodrich NP, Bayakly AR, Clarke CA, Copeland G, Finch JL, Fleissner ML, Goodman MT, Kahn A, Koch L, Lynch CF, Madeleine MM, Pawlish K, Rao C, Williams MA, Castenson D, Curry M, Parsons R, Fant G, Lin M (20I I) Spectrum of cancer risk among US solid organ transplant recipients. JAMA : the journal of the American Medical Association 306 (17): 1891-1901. doi:10.1001/jama.201 I.1592

Esashi E, Bao M, Wang YH, Cao W, Liu YJ (20I2) PACSINI regulates the TLR7/9-mediated type I interferon response in plasmacytoid dendritic cells. European journal of immunology 42 (3):573-579. doi: 10.1002/eji.20 I I42045

Friedenson B (2007) The BRCAI/2 pathway prevents hematologic cancers in addition to breast and ovarian cancers. BMC cancer 7:I52. doi:10.1 I86/I47I-2407-7-I52

Friedenson B (20I0a) Inflammation targets specific organs for cancer in carriers of BRCAI/2 pathway mutations. J Med Med Sci I (8):356-37I 
Friedenson $B(2010 b)$ Inflammatory processes inordinately increase tissue specific cancer risks in carriers of mutations in BRCAI, BRCA2, ATM or Fanconi anemia genes. Journal of Medicine and Medical Sciences I (8):356-37I

Friedenson B (20I0c) A theory that explains the tissue specificity of BRCAI/2 related and other hereditary cancers. Journal of Medicine and Medical Sciences I (8):372-384

Frisch M, Biggar RJ, Engels EA, Goedert JJ, Group AI-CMRS (200I) Association of cancer with AIDSrelated immunosuppression in adults. JAMA : the journal of the American Medical Association 285 (13): 1736-1745

Fu L, Lin-Lee YC, Pham LV, Tamayo A, Yoshimura L, Ford RJ (2006) Constitutive NF-kappaB and NFAT activation leads to stimulation of the BLyS survival pathway in aggressive B-cell lymphomas. Blood 107 (I I):4540-4548. doi:10.1 I 82/blood-2005-10-4042

Garcia-Sastre A (2013) Cell biology: Beneficial lessons from viruses. Nature. doi:10.1038/nature I1947

Gasser S, Orsulic S, Brown EJ, Raulet DH (2005) The DNA damage pathway regulates innate immune system ligands of the NKG2D receptor. Nature 436 (7054): I I86-I I 90. doi:10.1038/nature03884

Glenn WK, Heng B, Delprado W, lacopetta B, Whitaker NJ, Lawson JS (20 I2) Epstein-barr virus, human papillomavirus and mouse mammary tumour virus as multiple viruses in breast cancer. PloS one 7 ( I I):e48788. doi:10.137I/journal.pone.0048788

Gogvadze E, Stukacheva E, Buzdin A, Sverdlov E (2009) Human-specific modulation of transcriptional activity provided by endogenous retroviral insertions. Journal of virology 83 (I2):6098-6I 05. doi:I0.1 128/JVI.00123-09

Grady SL, Hwang J, Vastag L, Rabinowitz JD, Shenk T (20I2) Herpes simplex virus I infection activates poly(ADP-ribose) polymerase and triggers the degradation of poly(ADP-ribose) glycohydrolase. Journal of virology 86 (I5):8259-8268. doi: I0.I I 28/JVI.00495-I2

Gregorek H, Chrzanowska KH, Dzierzanowska-Fangrat K, Wakulinska A, Pietrucha B, Zapasnik A, Zborowska M, Pac M, Smolka-Afifi D, Kasztelewicz B, Piekutowska-Abramczuk D, Maldyk J (20I0) Nijmegen breakage syndrome: Long-term monitoring of viral and immunological biomarkers in peripheral blood before development of malignancy. Clinical immunology 135 (3):440-447. doi:10.1016/j.clim.2010.01.008

Hermsen BB, von Mensdorff-Pouilly S, Fabry HF, Winters HA, Kenemans P, Verheijen RH, van Diest PJ (2005) Lobulitis is a frequent finding in prophylactically removed breast tissue from women at hereditary high risk of breast cancer. The Journal of pathology 206 (2):220-223. doi:10.1002/path.1774

Hibberd AD, Trevillian PR, Wlodarczyk JH, Kemp DG, Stein AM, Gillies AH, Heer MK, Sheil AG (20I3) Effect of immunosuppression for primary renal disease on the risk of cancer in subsequent renal transplantation: a population-based retrospective cohort study. Transplantation 95 (I): I22-I27. doi:10.1097/TP.0b0 I3e3182782f59 
Hiscott J, Kwon H, Genin P (200 I) Hostile takeovers: viral appropriation of the NF-kappaB pathway. The Journal of clinical investigation 107 (2):I43-I5I. doi: I0.II72/JCII 1918

Holland JF, Pogo BG (2012) Comment on the review by Joshi and Buehring. Breast cancer research and treatment I36 (I):303-307. doi:10.1007/s I0549-0I2-2078-5

Ibrahim N, Wicklund A, Wiebe MS (20II) Molecular characterization of the host defense activity of the barrier to autointegration factor against vaccinia virus. Journal of virology 85 (22): I I 588I |600. doi: |0. I |28/JVI.0064| - I |

Jansson A, Johansson P, Yang W, Palmqvist L, Sjoblom-Hallen A, Rymo L (2007) Role of a consensus AP-2 regulatory sequence within the Epstein-Barr virus LMPI promoter in EBNA2 mediated transactivation. Virus genes 35 (2):203-2|4. doi:|0. I007/s| I 262-007-0I I6-X

Klein Wolterink RG, Serafini N, van Nimwegen M, Vosshenrich CA, de Bruijn MJ, Fonseca Pereira D, Veiga Fernandes H, Hendriks RW, Di Santo JP (2013) Essential, dose-dependent role for the transcription factor Gata3 in the development of IL-5+ and IL- 13+ type 2 innate lymphoid cells. Proceedings of the National Academy of Sciences of the United States of America 110 (25): I0240-10245. doi:10.1073/pnas. 1217158110

Ko NL, Birlouez E, Wain-Hobson S, Mahieux R, Vartanian JP (20I2) Hyperediting of human T-cell leukemia virus type 2 and simian T-cell leukemia virus type 3 by the dsRNA adenosine deaminase ADAR-I. The Journal of general virology 93 (Pt I2):2646-265I.

doi:I0.1099/vir.0.045 I46-0

Kosmaczewska A, Bocko D, Ciszak L, Wlodarska-Polinska I, Kornafel J, Szteblich A, Masternak A, Frydecka I (20I2) Dysregulated expression of both the costimulatory CD28 and inhibitory CTLA-4 molecules in PB T cells of advanced cervical cancer patients suggests systemic immunosuppression related to disease progression. Pathology oncology research : POR 18 (2):479-489. doi: I0.1007/s I2253-0 I I-947I-y

Kulinski JM, Leonardo SM, Mounce BC, Malherbe L, Gauld SB, Tarakanova VL (20I2) Ataxia telangiectasia mutated kinase controls chronic gammaherpesvirus infection. Journal of virology 86 (23): I 2826-I2837. doi: I 0. I I28/JVI.009 I7-I2

Lamy L, Ngo VN, Emre NC, Shaffer AL, 3rd, Yang Y, Tian E, Nair V, Kruhlak MJ, Zingone A, Landgren O, Staudt LM (20I3) Control of autophagic cell death by caspase-I0 in multiple myeloma. Cancer cell 23 (4):435-449. doi:10.1016/j.ccr.2013.02.017

Laurson J, Khan S, Chung R, Cross K, Raj K (2010) Epigenetic repression of E-cadherin by human papillomavirus 16 E7 protein. Carcinogenesis 31 (5):918-926. doi:I0.1093/carcin/bgq027

Lee JY, Park AK, Lee KM, Park SK, Han S, Han W, Noh DY, Yoo KY, Kim H, Chanock SJ, Rothman N, Kang D (2009) Candidate gene approach evaluates association between innate immunity genes and breast cancer risk in Korean women. Carcinogenesis 30 (9):। 528-I53।. doi:10.1093/carcin/bgp084

Levin B, Lech D, Friedenson B (20I2) Evidence that BRCAI - or BRCA2-associated cancers are not inevitable. Molecular medicine 18:1327-1337. doi:I 0.21 19/molmed.2012.00280 
Li D, Li S, Sun Y, Dong H, Li Y, Zhao B, Guo D, Weng C, Qiu HJ (20I3) Poly(C)-binding protein I, a novel npro-interacting protein involved in classical Swine Fever virus growth. Journal of virology 87 (4):2072-2080. doi: I0. I I28/JVI.02807-I 2

Li M, Zhao H, Zhang X, Wood LD, Anders RA, Choti MA, Pawlik TM, Daniel HD, Kannangai R, Offerhaus G], Velculescu VE, Wang L, Zhou S, Vogelstein B, Hruban RH, Papadopoulos N, Cai J, Torbenson MS, Kinzler KW (201 I) Inactivating mutations of the chromatin remodeling gene ARID2 in hepatocellular carcinoma. Nature genetics 43 (9):828-829. doi:10.1038/ng.903

Li Z, Ender C, Meister G, Moore PS, Chang Y, John B (2012) Extensive terminal and asymmetric processing of small RNAs from rRNAs, snoRNAs, snRNAs, and tRNAs. Nucleic acids research 40 (14):6787-6799. doi:10.1093/nar/gks307

Lin CW, Hsieh YS, Hsin CH, Su CW, Lin CH, Wei LH, Yang SF, Chien MH (2012) Effects of NFKBI and NFKBIA gene polymorphisms on susceptibility to environmental factors and the clinicopathologic development of oral cancer. PloS one 7 (4):e35078. doi:I0.137I/journal.pone.0035078

Liu S, Lachapelle J, Leung S, Gao D, Foulkes WD, Nielsen TO (2012) CD8+ lymphocyte infiltration is an independent favorable prognostic indicator in basal-like breast cancer. Breast cancer research : BCR I4 (2):R48. doi:I0.1 186/bcr3| 48

Liu X, Zhan Z, Xu L, Ma F, Li D, Guo Z, Li N, Cao X (20I0) MicroRNA-I48/I52 impair innate response and antigen presentation of TLR-triggered dendritic cells by targeting CaMKIlalpha. Journal of immunology I 85 (I2):7244-725 I. doi: I0.4049/jimmunol. I00 I 573

Lowy DR, Gillison ML (2003) A new link between Fanconi anemia and human papillomavirusassociated malignancies. Journal of the National Cancer Institute 95 (22):1648-1650

Mogensen TH (2009) Pathogen recognition and inflammatory signaling in innate immune defenses. Clinical microbiology reviews 22 (2):240-273, Table of Contents. doi:I 0.I I 28/CMR.0004608

Mogensen TH, Paludan SR (200I) Molecular pathways in virus-induced cytokine production. Microbiology and molecular biology reviews : MMBR 65 (I): I 3 I-I50.

doi:I0.I I28/MMBR.65.I.I3I-I50.200I

Muller AJ, DuHadaway JB, Donover PS, Sutanto-Ward E, Prendergast GC (2005) Inhibition of indoleamine 2,3-dioxygenase, an immunoregulatory target of the cancer suppression gene Bin I, potentiates cancer chemotherapy. Nature medicine II (3):3 I2-3 I 9. doi: $10.1038 / \mathrm{nml} 196$

Navarro MN, Sinclair LV, Feijoo-Carnero C, Clarke R, Matthews SA, Cantrell DA (20I2) Protein kinase D2 has a restricted but critical role in T-cell antigen receptor signalling in mature $\mathrm{T}$ cells. The Biochemical journal 442 (3):649-659. doi: I 0. I042/BJ20 I I 700

Nik-Zainal S, Alexandrov LB, Wedge DC, Van Loo P, Greenman CD, Raine K, Jones D, Hinton J, Marshall J, Stebbings LA, Menzies A, Martin S, Leung K, Chen L, Leroy C, Ramakrishna M, Rance R, Lau KW, Mudie LJ, Varela I, McBride DJ, Bignell GR, Cooke SL, Shlien A, Gamble J, Whitmore I, Maddison M, Tarpey PS, Davies HR, Papaemmanuil E, Stephens PJ, McLaren S, 
Butler AP, Teague JW, Jonsson G, Garber JE, Silver D, Miron P, Fatima A, Boyault S, Langerod A, Tutt A, Martens JW, Aparicio SA, Borg A, Salomon AV, Thomas G, BorresenDale AL, Richardson AL, Neuberger MS, Futreal PA, Campbell PJ, Stratton MR, the Breast Cancer Working Group of the International Cancer Genome C (20I2) Mutational Processes Molding the Genomes of 21 Breast Cancers. Cell I49 (5):979-993. doi:I0.1016/j.cell.2012.04.024

Pankiv S, Johansen T (2010) FYCOI: Linking autophagosomes to microtubule plus end-directing molecular motors. Autophagy 6 (4)

Pham TH, Kwon KM, Kim YE, Kim KK, Ahn JH (20I3) DNA Sensing-Independent Inhibition of Herpes Simplex Virus I Replication by DAI/ZBPI. Journal of virology 87 (6):3076-3086. doi:I0.I I28/JVI.02860-I2

Phee H, Dzhagalov I, Mollenauer M, Wang Y, Irvine DJ, Robey E, Weiss A (2010) Regulation of thymocyte positive selection and motility by GIT2. Nature immunology II (6):503-5 I I. doi:10.1038/ni. 1868

Pichlmair A, Lassnig C, Eberle CA, Gorna MW, Baumann CL, Burkard TR, Burckstummer T, Stefanovic A, Krieger S, Bennett KL, Rulicke T, Weber F, Colinge J, Muller M, Superti-Furga $\mathrm{G}(20 \mathrm{II}) \mathrm{IFITI}$ is an antiviral protein that recognizes 5'-triphosphate RNA. Nature immunology 12 (7):624-630. doi:10.1038/ni.2048

Popova A, Kzhyshkowska J, Nurgazieva D, Goerdt S, Gratchev A (20I2) Smurf2 regulates ILI7RB by proteasomal degradation of its novel binding partner DAZAP2. Immunobiology 217 (3):32I 328. doi:10.1016/j.imbio.20II.10.004

Porter D, Lahti-Domenici J, Keshaviah A, Bae YK, Argani P, Marks J, Richardson A, Cooper A, Strausberg R, Riggins GJ, Schnitt S, Gabrielson E, Gelman R, Polyak K (2003) Molecular markers in ductal carcinoma in situ of the breast. Molecular cancer research : MCR I (5):362-375

Poschke I, De Boniface J, Mao Y, Kiessling R (2012) Tumor-induced changes in the phenotype of blood-derived and tumor-associated $T$ cells of early stage breast cancer patients. International journal of cancer Journal international du cancer I3I (7): I6I I-I620. doi: $10.1002 /$ ijc. 27410

Pringle LM, Young R, Quick L, Riquelme DN, Oliveira AM, May MJ, Chou MM (20I2) Atypical mechanism of NF-kappaB activation by TREI 7/ubiquitin-specific protease 6 (USP6) oncogene and its requirement in tumorigenesis. Oncogene 31 (30):3525-3535.

doi:10.1038/onc.2011.520

Ramirez K, Chandler KJ, Spaulding C, Zandi S, Sigvardsson M, Graves BJ, Kee BL (20I2) Gene deregulation and chronic activation in natural killer cells deficient in the transcription factor ETSI. Immunity 36 (6):92I -932. doi:I0.10 I6/j.immuni.20I2.04.006

Rathinam VA, Vanaja SK, Fitzgerald KA (20I2) Regulation of inflammasome signaling. Nature immunology 13 (4):333-332. doi:I0.1038/ni.2237

Reid S, Schindler D, Hanenberg H, Barker K, Hanks S, Kalb R, Neveling K, Kelly P, Seal S, Freund M, Wurm M, Batish SD, Lach FP, Yetgin S, Neitzel H, Ariffin H, Tischkowitz M, Mathew CG, 
Auerbach AD, Rahman N (2007) Biallelic mutations in PALB2 cause Fanconi anemia subtype FA-N and predispose to childhood cancer. Nature genetics 39 (2):162-164.

doi:10.1038/ngl 947

Rogozin IB, Basu MK, Jordan IK, Pavlov YI, Koonin EV (2005) APOBEC4, a new member of the AID/APOBEC family of polynucleotide (deoxy)cytidine deaminases predicted by computational analysis. Cell cycle 4 (9): I $28|-| 285$

Samuel CE (20II) Adenosine deaminases acting on RNA (ADARs) are both antiviral and proviral. Virology 4II (2):180-193. doi:10.1016/j.virol.2010.12.004

Sarkis S, Belrose G, Peloponese JM, Jr., Olindo S, Cesaire R, Mesnard JM, Gross A (2013) Increased osteopontin expression in HTLV-I-associated myelopathy/tropical spastic paraparesis (HAM/TSP) patient cells is associated with IL-I 7 expression. Journal of clinical virology : the official publication of the Pan American Society for Clinical Virology. doi:10.1016/j.jcv.2013.05.006

Sengupta P, Xu Y, Wang L, Widom R, Smith BD (2005) Collagen alpha I (I) gene (COLIAI) is repressed by RFX family. The Journal of biological chemistry 280 (22):21 004-2 1014. doi:I0.1074/jbc.M4I3191200

Shi HX, Liu X, Wang Q, Tang PP, Liu XY, Shan YF, Wang C (20II) Mitochondrial ubiquitin ligase MARCH5 promotes TLR7 signaling by attenuating TANK action. PLoS pathogens 7 (5):el 002057 . doi: I0.137I/journal.ppat. 1002057

Spardy N, Duensing A, Charles D, Haines N, Nakahara T, Lambert PF, Duensing S (2007) The human papillomavirus type 16 E7 oncoprotein activates the Fanconi anemia (FA) pathway and causes accelerated chromosomal instability in FA cells. Journal of virology 81 (23): I 3265-I 3270. doi: I0.I I 28/JVI.0 I I 2 I-07

Staege MS, Lee SP, Frisan T, Mautner J, Scholz S, Pajic A, Rickinson AB, Masucci MG, Polack A, Bornkamm GW (2002) MYC overexpression imposes a nonimmunogenic phenotype on Epstein-Barr virus-infected B cells. Proceedings of the National Academy of Sciences of the United States of America 99 (7):4550-4555. doi:10.1073/pnas.072495599

Tornesello ML, Loquercio G, Tagliamonte M, Rossano F, Buonaguro L, Buonaguro FM (2010) Human papillomavirus infection in urine samples from male renal transplant patients. Journal of medical virology 82 (7): I I79-I I85. doi:10.1002/jmv.21784

Tuomela J, Sandholm J, Karihtala P, Ilvesaro J, Vuopala KS, Kauppila JH, Kauppila S, Chen D, Pressey C, Harkonen P, Harris KW, Graves D, Auvinen PK, Soini Y, Jukkola-Vuorinen A, Selander KS (2012) Low TLR9 expression defines an aggressive subtype of triple-negative breast cancer. Breast cancer research and treatment I35 (2):48 I-493. doi: 10.1007/s I0549-0I2$218 \mid-7$

Van Duyne R, Guendel I, Klase Z, Narayanan A, Coley W, Jaworski E, Roman J, Popratiloff A, Mahieux R, Kehn-Hall K, Kashanchi F (20I2) Localization and sub-cellular shuttling of HTLVI tax with the miRNA machinery. PloS one 7 (7):e40662. doi: I0.137//journal.pone.0040662 
Vesely MD, Kershaw MH, Schreiber RD, Smyth MJ (20I I) Natural innate and adaptive immunity to cancer. Annual review of immunology 29:235-27I. doi:I0.I I46/annurev-immunol-031210101324

Vorbach C, Capecchi MR, Penninger JM (2006) Evolution of the mammary gland from the innate immune system? BioEssays : news and reviews in molecular, cellular and developmental biology 28 (6):606-6I6. doi:10.1002/bies.20423

Wagner JE, Tolar J, Levran O, Scholl T, Deffenbaugh A, Satagopan J, Ben-Porat L, Mah K, Batish SD, Kutler DI, MacMillan ML, Hanenberg H, Auerbach AD (2004) Germline mutations in BRCA2: shared genetic susceptibility to breast cancer, early onset leukemia, and Fanconi anemia. Blood 103 (8):3226-3229. doi:1 0.1 I82/blood-2003-09-31 38

Wang D, Malo D, Hekimi S (2010) Elevated mitochondrial reactive oxygen species generation affects the immune response via hypoxia-inducible factor-I alpha in long-lived Mclk I+/- mouse mutants. Journal of immunology I84 (2):582-590. doi:I 0.4049/jimmunol.0902352

Watanabe T, Urano E, Miyauchi K, Ichikawa R, Hamatake M, Misawa N, Sato K, Ebina H, Koyanagi Y, Komano J (2012) The hematopoietic cell-specific Rho GTPase inhibitor ARHGDIB/D4GDI limits HIV type I replication. AIDS research and human retroviruses 28 (8):913-922. doi:I0.1089/AID.20II.0I80

Yamamoto SP, Okawa K, Nakano T, Sano K, Ogawa K, Masuda T, Morikawa Y, Koyanagi Y, Suzuki Y (20II) Huwe I, a novel cellular interactor of Gag-Pol through integrase binding, negatively influences HIV-I infectivity. Microbes and infection / Institut Pasteur I3 (4):339-349. doi:I0.1016/j.micinf.2010.12.002

Young GR, Eksmond U, Salcedo R, Alexopoulou L, Stoye JP, Kassiotis G (2012) Resurrection of endogenous retroviruses in antibody-deficient mice. Nature 49I (7426):774-778.

doi:10.1038/nature II599

Yuan J, Shan Y, Chen X, Tang W, Luo K, Ni J, Wan B, Yu L (2005) Identification and characterization of RHEBLI, a novel member of Ras family, which activates transcriptional activities of NFkappa B. Molecular biology reports 32 (4):205-2 I4. doi:I 0. I007/s I I 033-005-0984-X

Zhang Y, Fan S, Meng Q, Ma Y, Katiyar P, Schlegel R, Rosen EM (2005) BRCAI interaction with human papillomavirus oncoproteins. The Journal of biological chemistry 280 (39):33 I6533I77. doi: I0.1074/jbc.M505I 24200

Zhao H, Wang J, Han Y, Huang Z, Ying J, Bi X, Zhao J, Fang Y, Zhou H, Zhou J, Li Z, Zhang Y, Yang $X$, Yan T, Wang L, Torbenson MS, Cai J (20II) ARID2: a new tumor suppressor gene in hepatocellular carcinoma. Oncotarget 2 (I I):886-89I

Zheng Y, Humphry M, Maguire J], Bennett MR, Clarke MC (20I3) Intracellular interleukin-I receptor 2 binding prevents cleavage and activity of interleukin-I alpha, controlling necrosisinduced sterile inflammation. Immunity 38 (2):285-295. doi:I0.1016/j.immuni.2013.01.008

Ziauddin J, Schneider DS (2012) Where does innate immunity stop and adaptive immunity begin? Cell host \& microbe 12 (4):394-395. doi:I0.1016/j.chom.2012.10.004 
